\title{
Historical Periods
}

Nara Period

Heian Period

Kamakura Period

Period of North and South Courts

Muromachi Period

Warring States Period

Edo (Tokugawa) Period

Meiji Period

Taishō Period

Shōwa Period

Heisei Period
$710-784$

794-II85

II85-I333

1336-92

I392-I 573

I $477-1573$

I600-I867

1868-1912

$1912-26$

1926-89

1989-present 

Inventing the Classics 
